\author{
HENRYK LITWIN \\ https://orcid.org/0000-0001-9877-2196 \\ Uniwersytet Warszawski
}

\title{
PAWEŁ RZECHOWSKI VEL RECHOWSKI, PISARZ GRODZKI KIJOWSKI - ADAPTACJA POLAKA DO FUNKCJONOWANIA W ŚRODOWISKU SZLACHTY RUSKIEJ NA KIJOWSZCZYŹNIE W CZASACH ZYGMUNTA III
}

\begin{abstract}
Abstrakt: Paweł Rzechowski, zmarły w 1629 r., długoletni pisarz grodzki kijowski, jest przykładem adaptacji na ziemiach ukrainnych przybysza z ziem polskich. Jego kariera zaczęła się od działań o charakterze adwokackim w sądach wołyńskich i doprowadziła Rzechowskiego do pozycji lidera szlacheckiego w województwie kijowskim, wybieranego na posła i deputata do Trybunału. Rzechowski dostosował się do wymogów środowiska - znajomość języka ruskiego, lokalnego systemu prawnego (tzw. Statutu Wołyńskiego), szacunek dla prawosławia. Podobnych przykładów Polaków działających w pierwszej połowie XVII w. na ziemiach ukrainnych Rzeczypospolitej jest wiele.
\end{abstract}

Słowa kluczowe: Rzeczpospolita Obojga Narodów, społeczeństwo szlacheckie, szlachta ruska, województwo kijowskie, adaptacja.
Abstract: Paweł Rzechowski, who died in 1629 , a long-serving borough clerk of Kiev, is an example of the adaptation of a newcomer from the Polish lands to the Ukrainian lands. His career began with attorneyship in the courts of Volhynia. It led Rzechowski to the position of a leader of the nobility in the Kiev province, elected as a deputy and member of a deputation to the Tribunal. Rzechowski adapted to the requirements of his milieu - knowledge of the Ruthenian language, of the local legal system (the so-called Volhynian Statute), respect for the Orthodox Church. There are many similar examples of Poles operating in the first half of the seventeenth century in the Ukrainian lands of the Commonwealth.

Keywords: Polish-Lithuanian Commonwealth, noble society, Ruthenian nobility, Kiev province, adaptation. 
Klasycy polskiej heraldyki i genealogii epoki przełomu wieków XIX i XX, tacy jak Adam Boniecki (ur. 1842), Kazimierz Pułaski (ur. 1846) czy nieco starszy od nich Seweryn Uruski (ur. 1817) oraz wielu innych z pasją śledzili losy polskich rodów szlacheckich, których dzieje związane były z ziemiami przyłączonymi do Korony na mocy przywilejów lubelskich 1569 r. W swych pracach odtwarzali dzieje wołyńskich czy kijowskich gałęzi rodzin wywodzących się z Małopolski, Wielkopolski czy Mazowsza, które, nie tracąc swej genealogicznej i heraldycznej świadomości, wiązały swe losy z lokalnymi środowiskami odległych ziem nad Dnieprem, Styrem czy Bohem. W dziejach Charlęskich, Potockich h. Lubicz, Radzimińskich, Witowskich h. Jastrzębiec, Złotopolskich, Chmieleckich, Kaszowskich, Stępkowskich, Wolskich - by wymienić niektóre tylko, bardziej znane nazwiska - wyodrębniły się ruskie gałęzie, zadomowione na wiele pokoleń wokół Łucka, Kijowa czy Bracławia. Uwagę historyków zwracali też pojedynczy bohaterowie, którym udało się zrobić kariery na kresach Rzeczypospolitej, ale nie pozostawiwszy potomków „po mieczu” nie rozpoczęli wielopokoleniowych historii. Takimi jednoosobowymi, „ślepymi" gałęziami swych rodów byli np. Olbrycht (Wojciech) Kochanowski h. Korwin, sędzia ziemski bracławski i wielokrotny poseł na sejmy, Stanisław Wielam h. Radwan, promotor kalwinizmu na Kijowszczyźnie czy Maksymilian Oczesalski h. Paprzyca, podsędek, potem sędzia ziemski bracławski i również częsty uczestnik obrad sejmowych.

Podobnym przypadkiem jest bohater niniejszej opowieści, Paweł Rzechowski herbu Dąbrowa, tyle że, gdy tamci pochodzili z zamożnych średnioszlacheckich rodów Małopolski i Mazowsza, on był - rzec by można - migrantem zarobkowym, wywodzącym się ze szlacheckiej „okolicy” Rzechowo w ziemi różańskiej ${ }^{1}$. Pozostanie zapewne zagadką nie tylko, w jaki sposób udało mu się wyruszyć w szeroki świat, ale i jak dostał się do środowiska zupełnie odmiennego od tego, w którym się wychował. Jak wiadomo, dla mazowieckich szaraczków już od XIV w. nie było niczym nowym poszukiwanie fortuny na ziemiach ruskich, w ślad za czerskimi Piastowicami, którzy objęli panowanie w księstwie bełskim. To osadnictwo jest jednak dobrze zbadane i nie odnajdziemy żadnych śladów obecności rodu Rzechowskich w okolicach Bełza ${ }^{2}$. W istocie „wpadamy" na Pawła Rzechowskiego zupełnie niespodziewanie

1 S. Uruski, Rodzina. Herbarz szlachty polskiej, t. 1-15, Warszawa 1904-1931, t. 15, s. 364; B. Chlebowski, Rzechowo, w: SGKP, wyd. F. Sulimierski, B. Chlebowski, W. Walewski, t. 10, Warszawa 1880-1902, s. 128.

2 A. Janeczek, Osadnictwo pogranicza polsko-ruskiego. Województwo bełskie od schyłku XIV do początku XVII w., Wrocław 1991, passim. 
w dokumentacji sądów grodzkich w Krzemieńcu i Włodzimierzu w latach dziewięćdziesiątych XVI w. Natalia Starczenko (Natalâ Starčenko) odnotowała jego aktywność w charakterze „umocowanego" w 26 sprawach z lat 1595-1596 i 1598-15993. Działał zatem jako zastępca prawny, można powiedzieć w pewnym skrócie myślowym - adwokat, przed sądami wołyńskimi. Musiał być więc fachowcem w dziedzinie odrębnego wszak wołyńsko-kijowskiego systemu prawnego, opartego na II Statucie Litewskim i w lokalnej praktyce sądowej. Musiał także sprawnie posługiwać się językiem ruskim, formalnie obowiązującym w sądownictwie Wołynia, Kijowszczyzny i Bracławszczyzny, i - jak świadczą księgi sądowe z tego okresu - faktycznie używanym w przytłaczającej większości akt. Do opanowania takich umiejętności potrzebne było jakieś przygotowanie, można się zatem domyślać, że Rzechowski posiadał przyzwoite wykształcenie. Pod koniec XVI w. ubogiemu szlachcicowi mogło się to udać tylko dzięki służbie na dworze magnackim i życzliwości zamożnego patrona. Być może takiego sponsora trzeba szukać między zleceniodawcami sądowych zadań, którymi zajmował się na Wołyniu nasz bohater. Widzimy wśród nich przedstawicieli ruskiej średniej szlachty - Jakowickich, Szpakowskich, Owłuczymskich, Łahodowskich, Nowosieleckich, Bołharynów, Kostiuszkowiczów-Chobołtowskich, Łasków-Czernczyckich, Malińskich. Odnajdujemy zasiedziałą na Wołyniu szlachtę polską Grajewskich, Rajeckich, Gronowskich. Spotykamy też wołyńskich kniaziów - Adama Wiśniowieckiego, Jerzego Czartoryskiego, Poryckich ${ }^{4}$. Powtarzają się częściej tylko dwaj zleceniodawcy: Janusz kniaź Zasławski (cztery razy w latach 1595-1598) oraz Adam Prusinowski (również cztery razy w latach 1598-1599). W tym ostatnim można by się domyślać patrona Rzechowskiego, bowiem Prusinowscy wywodzili się z bliskiej miejscu pochodzenia bohatera tej opowieści ziemi zakroczymskiej i jeszcze przed unią lubelską objęli obszerne dobra w powiecie włodzimierskim, a wspomnianego wyżej Adama czekała kariera senatorska (kasztelan, potem wojewoda bełski), jednak w latach 1595-1603 pochłaniała go wojaczka, a i jego status majątkowy był jeszcze dość skromny ${ }^{5}$, więc na hojnego patrona raczej się wówczas nie nadawał. Mógłby nim być Janusz Zasławski, z którego rodziną łączyły Rzechowskiego trwałe więzi

${ }^{3}$ Н. Старченко, Умоцзовані - прокуратори - приятелі: Хто вони? (Становлення інституту адвокатури на Волині в кінці XVI cm.), „Соціум. Альманах соціальної історіï" 1, 2002, s. 139-144.

${ }^{4}$ Ibidem.

${ }^{5}$ H. Kowalska, Prusinowski h. Topór Adam, PSB, t. 28, Wrocław-Warszawa-Kraków 1984-1985. 
(potwierdzone także w latach 1604, 1616, 1617, 16186). Jednak wydaje się mało prawdopodobne, by kontakty z kniaziami z Zasławia były wcześniejsze niż przybycie Rzechowskiego na Wołyń.

W czasie swej adwokackiej aktywności na Wołyniu Rzechowski czerpał także dochody z różnych operacji finansowych. Zachowały się ślady rozliczeń jego pożyczek Matysowi kniaziowi Zbaraskiemu (1595) i Nestorowi Wesełowskiemu $(1601)^{7}$. W 1597 r. trafił pod skrzydła Konstantego kniazia Ostrogskiego - w kierowanym przez niego grodzkim urzędzie kijowskim pełnił funkcję podpiska, co odnotowała Natalia Jakowenko (Natalâ Âkovenko) ${ }^{8}$. Już jednak w czerwcu 1598 r. widzimy go na powrót na Wołyniu, oddającego się aktywności adwokackiej. Bywał wówczas także "obrońcą z urzędu”, jak w sprawie z października 1598 r., kiedy sąd grodzki łucki „przydał” Rzechowskiego jako „prokuratora do obrony" unickiego diaka Demjana Wasylewicza, oskarżonego o współudział w zabójstwie prawosławnego duchownego9. Jeszcze przez kilka kolejnych lat Rzechowski pozostawał na Wołyniu i trudnił się adwokaturą. Najpóźniejszy znany ślad tej działalności pochodzi z lutego 1604 r., kiedy po raz kolejny reprezentował interesy Janusza Zasławskiego ${ }^{10}$.

Po tym wydarzeniu Paweł Rzechowski na kilka lat znika nam z pola widzenia, po czym pojawia się znowu na Kijowszczyźnie w składzie powołanego przez nowego wojewodę, Stanisława Żółkiewskiego, urzędu grodzkiego. Na jego czele stał podwojewodzi Michał Myszka-Chołoniewski, prawosławny przedstawiciel pańskiego rodu wołyńskiego ${ }^{11}$. Sędzią grodzkim został także prawosławny ziemianin kijowski Michał Siła-Nowicki ${ }^{12}$, Rzechowskiego zaś powołano na urząd pisarza grodzkiego.

${ }^{6}$ Aleksander Zasławski do pisarza grodzkiego kijowskiego, 6 VI 1616, ANK, Archiwum Sanguszków ze Sławuty, nr 75, k. 40; regest wpisu do ksiąg ziemskich krzemienieckich z 23 II 1604 r., Кременецьький земський суд. Описи актових книг, red. І. Бутич, t. 1-3, Київ 1959-1965, t. 2, s. 134, regest wpisu do ksiąg grodzkich żytomierskich z 10 I 1617 r., Книга житомирская гродская записовая и поточная 1617 и 1618 годов, w: Опись актовой книги Киевскаго Централнаго Архива, nr 13, wyd. Л. В. Ильницкий, Киев 1882.

${ }^{7}$ Кременец̧ький земський суд, t. 1, s. 139 (wpis z 17 XI 1595), t. 2, s. 26 (wpis z 7 VIII 1601).

${ }^{8}$ Н. Яковенко, Матеріали до персонального складу канцелярій Волині, Наддніпрянщзини та Східного Поділля (остання третина XVI - середина XVII cm.), w: До джерел. Збірник наукових працъь на пошану Олега Купчинського, t. 1, Львів 2004, s. 146.

9 Архів Югозападной России издаваемий Временною Коммиссею для розбора Древных Актов, сz. 1-8, Киев 1859-1905, cz. 1, t. 6, s. 238.

${ }_{10}$ Кременецъький земський суд, t. 2, s. 134 (wpis z 23 II 1604).

${ }^{11}$ H. Litwin, Równi do równych. Kijowska reprezentacja sejmowa 1569-1648, Warszawa 2009, s. 41; idem, Napływ szlachty polskiej na Ukrainę 1569-1648, Warszawa 2000, s. 211.

12 H. Litwin, Napływ szlachty, s. 211. 
Pierwszy raz w tej roli został odnotowany w źródłach 10 marca 1609 r. ${ }^{13}$, ale nominacja była zapewne wcześniejsza i musiała nastąpić niebawem po objęciu przez hetmana polnego urzędu wojewódzkiego (28 III 1608) ${ }^{14}$. Pisarstwo grodzkie było niezwykle ważnym stanowiskiem, choć w hierarchii prestiżu niezbyt eksponowanym. Łączyło się z odpowiedzialnością za prowadzenie ksiąg grodzkich, wynikającym z tego stałym dochodem i udziałem w egzekucji decyzji urzędu na podległym terytorium obszernego powiatu kijowskiego ${ }^{15}$. Innymi słowy Rzechowski został ważnym członkiem zarządu administracyjnego województwa, występującym wraz z kolegami w imieniu nieobecnego najczęściej w Kijowie Żółkiewskiego. W latach 1609-1618, tzn. do objęcia przez hetmana urzędu kanclerskiego, obserwujemy stałą administracyjną i sądową aktywność Rzechowskiego, który brał udział w sesjach sądu, działaniach egzekucyjnych i administracyjnych na terenie województwa, budując coraz silniejszą pozycję w lokalnej społeczności. Pamiętajmy też, że prowadzenie ksiąg grodzkich było związane z niemałym i regularnym dochodem. Jednocześnie pisarz prowadził efektywną działalność gospodarczą w postaci udzielania pożyczek pod zastaw dóbr ziemskich, dzierżawienia majątków miejscowych właścicieli i prowadzenia rozmaitych transakcji o charakterze handlowym. Zachowały się liczne ślady takiej jego aktywności. W 1605 r. udzielił pożyczki pod zastaw Fryderykowi Tyszkiewiczowi, który potem zalegał z jej zwrotem, co stało się przyczyną pozwu aktykowanego w grodzie żytomierskim ${ }^{16}$. W latach 1611-1618 wraz z Janem Czerchawskim dzierżawił u Surynów wsie Hażyn i Wystupowicze ${ }^{17}$. Od roku 1617 przez co najmniej dwa lata dzierżawił od Aleksandra kniazia Zasławskiego (syna Janusza) całe starostwo żytomierskie, co przynosiło bez wątpienia znaczną intratę ${ }^{18}$. Zajmował się także transakcjami handlowymi, jak np. w roku 1611, kiedy wykupił u Adama Szklarskiego prawo do zajęcia

${ }^{13}$ Книга житомирская гродская записовая и поточная 1611 года, w: Опись актовой книги Киевскаго Централнаго Архива, nr 12, wyd. И.П. Новицкий, Киев 1877, s. 7.

${ }^{14}$ Urzędnicy województw kijowskiego i czernihowskiego XV-XVIII wieku. Spisy, oprac. E. Janas, W. Kłaczewski, Kórnik 2001, s. 67.

${ }^{15}$ H. Litwin, Równi do równych, s. 92.

16 Ділова мова Волині і Наддніпрянщини XVII cm. (збірник актових документів), red. В.В. Німчук, Київ 1981, s. 109 (17 IV 1605).

17 Книга житомирская гродская записовая и поточная 1611 года, s. 27; Ziemie ruskie: Ukraina (Kijów-Bracław), dział 1-3, wyd. A. Jabłonowski, Warszawa 1894 (Polska XVI wieku pod względem geograficzno-statystycznym, t. 9-11, w serii Źródła Dziejowe, t. 20-22), dz. 2, s. 233, 279.

${ }_{18}$ Книга житомирская гродская записовая и поточная 1617 и 1618 годов, w: Опись актовой книги, nr 13, wyd. Л.В. Ильницкий, Киев 1882, s. 4 (10 I 1617); Ziemie ruskie: Ukraina, dz. 2, s. 220. 
50 łasztów popiołu, które miały być dostarczone przez Stefana Biesiekierskiego, ten jednak zalegał z dostawą ${ }^{19}$. Rzechowski liczył zapewne, że jego możliwości egzekucyjne będą skuteczniejsze niż pierwszego kontrahenta. Nierozstrzygnięte pozostaje pytanie, czy popiół miał być przeznaczony do sprzedaży, czy też do własnej produkcji potażu. W późniejszych latach „trzymał” zastawem majętności Charlęskich Stawek, Juriewka i Wojtaszowka, liczące sobie łącznie ponad 80 dymów $^{20}$. Dzierżawił też lub był użytkownikiem zastawnym obszernych majątków Olizarów - Korostyszew i Toporzyszcze ${ }^{21}$. W każdym razie widzimy, że Rzechowski stał się człowiekiem zamożnym, choć o ile nam wiadomo nie zakupił na Kijowszczyźnie żadnych dóbr, a zadowalał się jedynie użytkowaniem tymczasowym, co i tak dawało mu pozycję szlachcica „osiadłego”. Nawiasem mówiąc, brak też jakichkolwiek zapisów na temat jego rodziny. Najprawdopodobniej był bezżenny i bezdzietny, choć to przypadek bardzo rzadki wśród ówczesnej szlachty stanu świeckiego.

Dobrze sprawowany urząd i rosnąca zamożność przyczyniały się do umocnienia pozycji Rzechowskiego w lokalnej społeczności. Wyrazem jej zaufania było obranie pisarza grodzkiego deputatem na Trybunał Koronny, obok Wacława Wielhorskiego, na sejmiku odbytym w Żytomierzu 12 września 1611 r., pod laską Filona Strybyla, cześnika kijowskiego ${ }^{22}$. Jeszcze ważniejszym dla niego wydarzeniem był zapewne wybór na posła województwa kijowskiego dokonany na sejmiku przed drugim sejmem 1613 r. Jego kolegami byli wówczas podkomorzy kijowski Samuel Hornostaj i cześnik kijowski Filon Strybyl ${ }^{23}$. W 1618 r. Rzechowski ponownie znalazł się wśród kijowskich posłów na sejm obok Stefana Niemirycza ${ }^{24}$. Można te fawory miejscowej szlachty tłumaczyć pozycją Żółkiewskiego i jego wpływami na sejmiku, ale można też być pewnym, że hetman nie promował na posła byle kogo i dbał, aby bracia-szlachta mogli „dać kreskę” godnemu kandydatowi. Wiadomo zresztą, że pisarz grodzki miał dobre notowania wśród ważnych aktorów lokalnej sceny politycznej. Do „przyjaciół” zaliczali go Jerzy Lasota i Stefan Niemirycz ${ }^{25}$.

19 Актова книга Житомирського гродського уряду 1611 року, wуd. А.М. Матвієнко, B.М. Мойсієнко, Київ-Житомир 2002, s. 244-246 (wpis z 20 III 1611).

20 Архів Югозападной России, сz. 7, t. 1, s. 358.

${ }^{21}$ Paweł Rzechowski do Tomasza Zamoyskiego, miejsce i data na obu listach nieczytelne, AGAD, Archiwum Zamoyskich, 740, k. 59, 60.

${ }^{22}$ Книга житомирская гродская записовая и поточная 1611 года, s. 28 (wріs z 12 IX 1611).

${ }^{23}$ H. Litwin, Równi do równych, s. 91.

${ }^{24}$ Ibidem.

${ }^{25}$ Актова книга Житомирського гродського уряду, s. 239-241 (wріs z 9 III 1611). 
Wprowadzało go to w kijowskie „dobre towarzystwo", do którego należeli też Woroniczowie, Stryblowie, Jelcowie, Butowiczowie, stanowiące zresztą - prócz arianina Niemirycza - miejscową elitę obrońców prawosławia. Stanisław Żółkiewski powierzał też Rzechowskiemu reprezentowanie swoich interesów w sprawach sądowych związanych z działaniami urzędu wojewodzińskiego ${ }^{26}$. Właśnie hetman-wojewoda określił dobitnie pozycję Rzechowskiego w lokalnej społeczności w swoim liście z 26 maja 1619 r., zawierającym rady i przestrogi dla przejmującego po nim województwo kijowskie Tomasza Zamoyskiego: „Racz go WM zażywać, człowiek to dobry i godny i dobrego zachowania w tamtym kraju"27.

Tomasz Zamoyski, który objął urząd wojewody w marcu 1618 r., w istocie zażywał pisarza grodzkiego. Pozostawił go na urzędzie, na którym Rzechowski utrzymał się co najmniej do przeniesienia Zamoyskiego na podkanclerstwo 11 lipca $1628 \mathrm{r}^{28}$ Najprawdopodobniej pełnił swe obowiązki dłużej, przy kolejnym wojewodzie Aleksandrze Zasławskim, z którym już wcześniej był silnie związany. W każdym razie źródła potwierdzają, że jeszcze jesienią 1628 r., czyli już po nominacji dla Zasławskiego (1628, przed 30 sierpnia $)^{29}$, Rzechowski był wymieniany z urzędem pisarza grodzkiego ${ }^{30}$. Najprawdopodobniej rychło potem zmarł, bowiem od 1629 r. nie odnotowujemy żadnych wzmianek źródłowych na jego temat.

W latach 1618-1628 Rzechowski utrzymywał kontakt korespondencyjny z wojewodą i informował go o ważnych wydarzeniach na Kijowszczyźnie. W Archiwum Zamoyskich zachowało się kilka jego listów do wojewody ${ }^{31}$. Zakres tematyczny informacji był szeroki. Pisarz grodzki relacjonował przebieg roczków sądowych, sejmików, kłopoty kijowskich prominentów, sprawy związane z zagrożeniem tatarskim, nastroje wśród Kozaków, sytuację na pograniczu moskiewskim, żołnierskie „swawoleństwa" czy wreszcie wizytę patriarchy Teofanesa. Był bez wątpienia osobą dobrze poinformowaną i cieszącą się uznaniem. W 1619 r. został przez Zygmunta III wyznaczony - obok biskupa kijowskiego Bogusława Radoszewskiego, sędziego ziemskiego Jana Aksaka i podsędka ziemskiego kijowskiego Piotra Złotopolskiego - do składu specjalnej komisji, która

${ }^{26}$ Архів Югозападной России, сz. 8, t. 5, s. 376.

27 Н. Білоус, Між політикою і повсякденням: з історії стосунків коронного гетьмана Станіслава Жолкевського з київським воєводою Томашем Замойським (у світлі листування 1619-1620 pp.), „Україна в Центрально-Східній Європі” 14, 2014, s. 289.

28 Urzędnicy, s. 67.

29 Ibidem.

30 Архів Югозападной России, сz. 7, t. 1, s. 358.

${ }^{31}$ Korespondencja Rzechowskiego z T. Zamoyskim, AGAD, Archiwum Zamoyskich, sygn. 409, k. 1 , sygn. 740, k. 59, 60. 
miała zbadać okoliczności zabójstwa Antoniego Hrekowicza, unickiego namiestnika metropolity Józefa Welamina Rutskiego ${ }^{32}$. W roku 1620 po raz trzeci został wybrany na posła na sejm obok sędziego ziemskiego kijowskiego Aksaka ${ }^{33}$. Po jego działalności sejmowej nie zachowało się wiele śladów. Wiadomo, że w 1613 r. został wyznaczony do komisji ds. retent (niespłaconych należności podatkowych) ${ }^{34}$, w 1620 r. zaś wybrany na deputata do skarbu radomskiego ${ }^{35}$. Kijowska reprezentacja na wszystkich sejmach, w których uczestniczył Rzechowski, zajmowała stanowisko przychylne planom króla, choć w 1618 i 1620 r. upominała się także o uspokojenie religii greckiej ${ }^{36}$.

Niewątpliwe powiązania ze Stanisławem Żółkiewskim i Tomaszem Zamoyskim, którzy powoływali Rzechowskiego na urząd w sądzie grodzkim, nie przeszkadzały pisarzowi pozostawać w relacjach klientalnych z Zasławskimi, a w szczególności z kniaziem Aleksandrem, wojewodą bracławskim (od 1615), a później kijowskim (od 1628) i starostą żytomierskim. W zbiorach Archiwum Narodowego w Krakowie w korespondencji kniazia wojewody, zachowanej w Archiwum Sanguszków, odnajdujemy regesty listów księcia pisanych do Rzechowskiego ${ }^{37}$. Świadczą one, że pisarz grodzki był klientem Zasławskich i działał w ich interesach na terenach województwa kijowskiego, wszakże nie jako oficjalista, a „przyjaciel”, do którego „łaskawości” odwołuje się kniaź w końcowych formułach swej korespondencji. Listy Zasławskiego do „pana pisarza kijowskiego" były przy tym pisane z pewnym epistolograficznym zacięciem (choć nie wszystkie), pojawiały się w nich literackie aluzje i żartobliwe koncepty. Z ich lektury wynika, że kniaź wojewoda odnosił się do Rzechowskiego jako do wykonawcy poleceń, którego jednak należy traktować z pewną atencją i dbać o jego poczucie godności. Działania podejmowane

32 List Zygmunta III do biskupa kijowskiego Bogusława Radoszewskiego, Warszawa 6 VII 1619, Документи до історії унії на Волині і Київщині кінця XVI - першої половини XVII cm., w: Архів української цеекви, t. 1: Пам'ятки: [археогр. щзорічник], t. 3, wуd. М.В. Довбищенко, Київ 2001, s. 361.

${ }^{33}$ H. Litwin, Równi do równych, s. 91.

34 VC 3/1, s. 175.

35 Ibidem, s. 276.

36 J. Byliński, Dwa sejmy z 1613 roku, Wrocław 1984, s. 222-223; J. Seredyka, Sejm 1618 roku, Opole 1988, s. 181-182; J. Pietrzak, Po Cecorze i podczas wojny chocimskiej. Sejmy z lat 1620 i 1621, Wrocław 1983, s. 71-72, 82, 99-100.

${ }^{37}$ Dziękuję Panu Ihorowi Teslence za udostępnienie fragmentów przygotowanej do druku edycji korespondencji Aleksandra Zasławskiego, z listami do Rzechowskiego z 4, 15, 21, 24 XII 1616, 13, 14 III, 12 V, 31 VIII, 13 IX, 11 X, 1 XI, 19 XII 1617, 26 III, 8 IV, 31 V, 2 VI, 23 VIII i 19 IX 1618, ANK, Archiwum Sanguszków ze Sławuty, nr 75, t. 1, k. 40, 73, 101, 103, 105, 170, 171, 221, 288, 289, 299, 317, 332, 361, 458, 472-3, 493, 542-543, 556-557. 
przez Rzechowskiego na rzecz Zasławskiego miały różny charakter. Czasem chodziło o sięgnięcie do kiesy czy dokonanie określonego zakupu, a czasem o zastępstwo „honorowe”, jak np. wyręczenie podróżującego po Koronie księcia w obowiązkach testamentowego opiekuna rodziny zmarłego Adama Olizara. Rzechowski reprezentował interesy kniazia Aleksandra na rokach i roczkach kijowskich i był też zaufanym współpracownikiem w sprawach publicznych. Świadczą o tym choćby przygotowania do kampanii sejmikowej w grudniu 1617 r., kiedy Zasławski wysłał Rzechowskiemu „membrany” (czyli podpisane przez siebie listy z pozostawionym wolnym miejscem na wstawienie adresata) do rozdysponowania wśród szlachty kijowskiej mającej się zebrać w Żytomierzu. Z przywołanej korespondencji wynika, że wspomniane już dzierżawienie starostwa żytomierskiego było korzyścią uzyskaną w ramach klientalnej relacji opartej na obopólnym interesie. Trzeba więc założyć, że stosunki Rzechowskiego z Zasławskimi miały trwalszy charakter, niż relacje z Żółkiewskim czy Zamoyskim, ale też zauważmy, że „nierówna przyjaźń" z Zasławskimi nie przeszkadzała pisarzowi grodzkiemu wchodzić w podobne układy z innymi magnatami, a wszystko razem raczej wzmacniało jego prestiż w lokalnej społeczności szlacheckiej, niż mu szkodziło.

Osobnego rozważenia wymaga kwestia stosunku Rzechowskiego do kultury ruskiej, ruskiego języka i prawosławia. Jako pisarz grodzki musiał rzecz jasna posługiwać się, sprawnie językiem ruskim. Ciekawe jednak, że także podpisywał się, używając alfabetu cyrylicznego i nawet zrutenizował brzmienie swojego nazwiska, sygnując dokumenty jako Реховский. Zachowało się wiele takich podpisów ${ }^{38}$. Gdyby jednak ktoś chciał wątpić w polskie pochodzenie Rzechowskiego, byłoby to zbyt daleko idące rozumowanie. Dzięki Olegowi Odnorożence (Oleg Odnoroženko), który zechciał użyczyć mi danych ze swojego imponującego zbioru kopii odcisków pieczętnych szlachty ruskiej, można stwierdzić, że pisarz kijowski pieczętował się herbem Dąbrowa, tym samym, którym szczyciła się szlachecka okolica w mazowieckim Rzechowie ${ }^{39}$. Zachowały się też jego polskie podpisy pod dokumentami ${ }^{40}$, na których widnieje wyraźnie wersja nazwiska Rzechowski - w tym brzmieniu całkowicie nie nadaje się ono do uznania je za ruskie. Brak też w źródłach badanej epoki wiadomości o jakimkolwiek innym Rechowskim na terenach Kijowszczyzny, Wołynia i Bracławszczyzny.

${ }^{38}$ Na przykład: Wypis z ksiąg grodzkich kijowskich z 9 III 1627, ANK, Archiwum Dóbr Pomorzany, nr 93, k. 31; odpisy z akt sądowych kijowskich z 24 V 1612, 25 VIII 1613 i 3 VII 1614, BPAU-PANKr., rkp. 3387, k. 17, 21, 37.

39 S. Uruski, op. cit., t. 15, s. 364.

${ }^{40}$ Np. Актова книга Житомирського гродського уряду, s. 241 (wpis z 9 III 1611). 
Ciekawą kwestią jest stosunek Rzechowskiego do spraw wyznaniowych. Przed laty sam byłem zwolennikiem tezy, że pisarz stał się w czasie pobytu na Kijowszczyźnie prawosławny ${ }^{41}$. Świadczyć by o tym mógł jego udział w elekcji Zachariasza Kopystenskiego na archimandrię peczerską w $1624 \mathrm{r}^{42}$ Także postawa sądu grodzkiego kijowskiego z Rzechowskim włącznie w czasie sporów unicko-prawosławnych w Kijowie w latach 1611-1624 potwierdzać by mogła jego sympatie dla „religii greckiej" ${ }^{43}$. Jednak uważna lektura jednego z dokumentów dotyczących Rzechowskiego, a mianowicie mandatu królewskiego wyznaczającego skład komisji ds. zbadania okoliczności śmierci unity Hrekowicza w Kijowie w 1618 r., prowadzi do innego wniosku. Zygmunt III, powołując członków komisji w osobach biskupa kijowskiego Bogusława Radoszewskiego, Jana Aksaka, Piotra Złotopolskiego i Rzechowskiego, w wydanym po rusku akcie nominacyjnym wyraził przekonanie, że ich „vera, cnota i bogobojnost jest dobre vedoma" ${ }^{44}$. Trudno wątpić, że królowi mogło chodzić jedynie o bogobojność katolicką. Trzeba więc przyjąć, że pisarz pozostał wierny katolicyzmowi, a w elekcji Kopystenskiego wziął udział jako urzędnik województwa kijowskiego, a nie wyznawca prawosławia. Nie był zresztą jedyną osobą $\mathrm{w}$ podobnej sytuacji. Widzimy bowiem wśród elektorów Kopystenskiego sprawujących urzędy ziemskie kijowskie kolejnego katolika - podczaszego Łukasza Witowskiego oraz niewątpliwego arianina - podkomorzego Stefana Niemirycza ${ }^{45}$.

W osobie Rzechowskiego mamy zatem do czynienia z wywodzącym się z mazowieckiej „okolicy” polskim szlachcicem, który na Wołyniu i Kijowszczyźnie zrobił karierę zawodową, majątkową i polityczną, dzięki znajomości prawa, umiejętnemu korzystaniu z opieki różnych protektorów oraz zdolnościom do udanych operacji finansowych. Warto przy tym podkreślić, jak silnie przybysz z Korony zżył się ze środowiskiem lokalnym, jak gruntownie przystosował się do jego wymogów i językowych, i prawnych, i obyczajowych, włączając w to szacunek dla prawosławia. Takich Rzechowskich było w pierwszej połowie XVII w. na Kijowszczyźnie, Wołyniu i Bracławszczyźnie wielu. Liczni Polacy pracowali wówczas

${ }^{41}$ H. Litwin, Równi do równych, s. 92.

${ }^{42}$ С.Т. Голубев, Киевский митрополит Петр Могила и его сподвижники: (опыт исторического исследования), t. 1, Киев 1883, Приложение, s. 272.

${ }^{43}$ Zob. wypis z ksiąg sądowych kijowskich z 4 X 1611, w: Архив Югозападной России, cz. 1, t. 6, s. 399-402; a także podobne wypisy z 10 III 1614, 16 XII 1614, w: Документи до історії унії, s. 354, 354-355.

44 Документи до історії унії, s. 361.

${ }^{45}$ С.Т. Голубев, ор. cit., Приложение, s. 272; zob. H. Litwin, Struktura wyznaniowa szlachty kijowskiej 1569-1648, OiRP 48, 2004, s. 207, 215. 
w kancelariach grodzkich województw inkorporowanych. Cyrylicznego podpisu używali także Wojciech Rylski, pisarz grodzki kijowski 1632-1649, Jan Przygałkowski, pisarz grodzki owrucki 1640-1641, Jan Szydłowski, pisarz grodzki żytomierski 1646-1655, a także pisarze grodzcy winniccy Maciej Libuski (1623-1628), Jan Witwicki (1629-1635), Piotr Dąbrowski (1638-1645) i Mateusz Czaplicki (1645-1650). Również na Wołyniu, wśród pisarzy grodzkich przestrzegających tych samych zasad w kwestii języka urzędowego, często pojawiali się w tym czasie Koroniarze - np. Marcjan Olszamowski (1624-1627) i Walenty Buski (1637-1644) we Włodzimierzu, a Jan Budziński (1618-1624) i Stanisław Kazimierz Bieniewski (1641-1657) w Łucku. Jak się okazuje od lat dwudziestych XVII w. o utrzymanie roli języka ruskiego jako urzędowego na Ukrainie i Wołyniu dbali w praktyce głównie Polacy. Wkład przybyszy z Korony w pielęgnowanie ruskiej tradycji językowej w kancelariach Wołynia i Ukrainy jest ważnym elementem obrazu ukazującego charakter napływu Polaków do województw inkorporowanych w okresie 1569-1648.

\section{Streszczenie}

Kariera Pawła Rzechowskiego jest ciekawym przykładem adaptacji na ziemiach ruskich (województwo kijowskie) przybysza z ziem polskich (Mazowsze). Rzechowski pojawia się pod koniec XVI w. na Wołyniu, jako „umocowany” reprezentant stron procesowych w różnych sprawach sądowych. Był klientem rodu kniaziów Zasławskich i dzięki tej protekcji zyskał urząd pisarza grodzkiego kijowskiego, na który wprowadził go wojewoda kijowski Konstanty Wasyl kniaź Ostrogski. Zdobył sobie uznanie i popularność w województwie kijowskim, a następcy Ostrogskiego Stanisław Żółkiewski, Tomasz Zamoyski i Aleksander kniaź Zasławski utrzymali go na pisarstwie. Bez wątpienia był znawcą obowiązującego na Wołyniu i Ukrainie II Statutu Litewskiego (zwanego często Statutem Wołyńskim) i biegle posługiwał się językiem ruskim, a nawet podpisywał się przy użyciu alfabetu cyrylicznego, używając zrutenizowanej formy swego nazwiska - Rechowskij. Odnosił się z szacunkiem do prawosławia i brał udział w zjazdach szlachty prawosławnej, choć osobiście pozostał katolikiem. Był znaczącym uczestnikiem życia sejmikowego Kijowszczyzny, wybieranym na posła i deputata do Trybunału. Jego pozycji w społeczności lokalnej nie przeszkadzało utrzymywanie klientalno-patronackich więzi z rodem kniaziów Zasławskich. W starostwach grodzkich Wołynia i Ukrainy w pierwszej połowie XVII w. funkcjonowało wielu podobnych do Rzechowskiego urzędników wywodzących się z Polski, ale wiedzą prawniczą i umiejętnościami językowymi dostosowanych do lokalnych potrzeb. 


\section{Paweł Rzechowski vel Rechowski, Borough Clerk of Kiev - Adaptation of a Pole to Functioning in the Milieu of Ruthenian Nobility in the Province of Kiev under King Sigismund III}

Paweł Rzechowski's career is an interesting example of the adaptation of a newcomer from the Polish lands (Mazovia) to the Ukrainian lands (Kiev Province). Rzechowski appeared at the end of the sixteenth century in Volhynia as an 'empowered' attorney acting on behalf of litigants in various court cases. He was a client of the knyaz family of Zasławskis, and thanks to their patronage, he was appointed to the office of Kiev borough clerk by Prince Konstanty Wasyl Ostrogski, the Voivode of Kiev. Rzechowski gained recognition and popularity in the Province of Kiev, and Ostrogski's successors - Stanisław Żółkiewski, Tomasz Zamoyski, and Aleksander Zasławski - kept him on the post. He was undoubtedly an expert in the Second Lithuanian Statute (often referred to as the Volhynian Statute), which was in force in Volhynia and Ukraine. He was also fluent in Ruthenian and even signed himself in the Cyrillic alphabet using a Ruthenised form of his surname - Rechowskij. He respected the Orthodox Church and participated in conventions of the Orthodox nobility, although personally, he remained a Catholic. He was an important and active member of the Kiev regional sejmiks, elected as a deputy and member of the deputation to the Tribunal. His position in the local community was not undermined by client-patronage ties with the family of Princes Zasławskis. In the first half of the seventeenth century, in the districts (Polish: starostwa) of Volhynia and Ukraine, many officials like Rzechowski were of Polish origins but with legal knowledge and language skills adapted to local needs.

\section{Bibliografia}

Byliński Janusz, Dwa sejmy z 1613 roku, Wydawnictwo UWr, Wrocław 1984.

Chlebowski Bronisław, Rzechowo, w: SGKP, wyd. Filip Sulimierski, Bronisław Chlebowski, Władysław Walewski, t. 10, Warszawa 1880-1902, nakł. Filipa Sulimierskiego i Władysława Walewskiego, s. 128.

Janeczek Andrzej, Osadnictwo pogranicza polsko-ruskiego. Województwo bełskie od schytku XIV do poczatku XVII w., Ossolineum, Wrocław 1991.

Kowalska Halina, Prusinowski h. Topór Adam, PSB, t. 28, Wrocław-Warszawa-Kraków 1984-1985, s. 584.

Litwin Henryk, Napływ szlachty polskiej na Ukrainę 1569-1648, Semper, Warszawa 2000.

Litwin Henryk, Równi do równych. Kijowska reprezentacja sejmowa 1569-1648, DiG, Warszawa 2009.

Litwin Henryk, Struktura wyznaniowa szlachty kijowskiej 1569-1648, „Odrodzenie i Reformacja w Polsce" 48, 2004, s. 199-220.

Pietrzak Jerzy, Po Cecorze i podczas wojny chocimskiej. Sejmy z lat 1620 i 1621, Wydawnictwo UWr, Wrocław 1983. 
Seredyka Jan, Sejm 1618 roku, Wyższa Szkoła Pedagogiczna im. Powstańców Śląskich, Opole 1988.

Ziemie ruskie: Ukraina (Kijów-Bracław), dział 1-3, wyd. Aleksander Jabłonowski, Gebethner i Wolff, Warszawa 1894 (Polska XVI wieku pod względem geograficzno-statystycznym, t. 9-11, Źródła Dziejowe, t. 20-22).

Uruski Seweryn, Rodzina. Herbarz szlachty polskiej, t. 1-15, Gebethner i Wolff, Warszawa 1904-1931.

Urzędnicy województw kijowskiego i czernihowskiego XV-XVIII wieku. Spisy, oprac. Eugeniusz Janas, Witold Kłaczewski, Biblioteka Kórnicka, Kórnik 2001.

Актова книга Житомирського гродського уряду 1611 року, wуd. Антоніна М. Матвієнко, Віктор М. Мойсієнко, Національна Академія Наук України, Київ-Житомир 2002.

Архів Югозападной России издаваемий Временною Коммиссею для розбора Древных Актов, сz. 1-8, Университетская Типографія, Киев 1859-1905.

Білоус Наталя, Між політикою і повсякденням: з історії стосунків коронного гетьмана Станіслава Жолкевського з київським воєводою Томашем Замойським (у світлі листування 1619-1620рр.), „Україна в Центрально-Східній Європі” 14, 2014, s. 268-301.

Голубев Степан Т., Киевский митрополит Петр Могила и его сподвижники: (опыт исторического исследования), t. 1, Типографія Ф. Т. Корчак-Новіцкаго, Киев 1883.

Ділова мова Волині і Наддніпрянщзин XVII cm. (збірник актових документів), red. Василь В. Німчук, Академія наук Української РСР, Київ 1981.

Документи до історії унії на Волині і Київщині кінияя XVI - першої половини XVII cm., w: Архів української иеркви, t. 1, „Пам'ятки: [археогр. щорічник]”, t. 3, wyd. Михайло. В. Довбищенко, Державний комітет архівів України, Київ 2001.

Книга житомирская гродская записовая и поточная 1611 года, w: Опись актовой книги Киевскаго Централнаго Архива, nr 12, wуd. Иван П. Новицкий, Университетская Типографія, Киев 1877.

Книга житомирская гродская записовая и поточная 1617 и 1618 годов, w: Опись актовой книги Киевскаго Централнаго Архива, nr 13, wyd. Лука В. Ильницкий, Университетская Типографія, Киев 1882.

Кременец̧ький земський суд. Описи актових книг, red. Іван Бутич, t. 1-3, Центральний Державний Історичний Архів Української РСР у м. Києві, Київ 1959-1965.

Старченко Наталя, Умоцзовані - прокуратори - приятелі: Хто вони? (Становлення інституту адвокатури на Волині в кінцуі XVI cm.), „Соціум. Альманах соціальної історії" 1, 2002, s. 111-144.

Яковенко Наталя, Матеріали до персонального складу каниелярій Волині, Наддніпрянщини та Східного Поділля (остання третина XVI - середина XVII cm.), w: До джерел. Збірник наукових працьь на пошану Олега Купчинського, red. Ігор Гирич, Ярослав Грицак, Микола Крикун, Леонід Рудницький, Наталія Яковенко t. 1, Інститут української археографії та джерелознавства ім. М.С. Грушевського НАН України, Київ-Львів 2004, s. 320-357. 
Biogram: dr hab. Henryk Litwin, prof. Uniwersytetu Warszawskiego, pracownik Studium Europy Wschodniej. Prowadzi badania dotyczące działań dyplomacji papieskiej w Europie Środkowo-Wschodniej w XVI i XVII w., dziejów szlachty ruskiej w Rzeczypospolitej Obojga Narodów w okresie 1569-1648 oraz polskiej myśli politycznej drugiej połowy XV i początków XVI w. Zajmuje się też edytorstwem źródeł historycznych; kontakt: h.litwin@uw.edu.pl.

Author: Henryk Litwin, PhD with habilitation, prof. of the University of Warsaw, employee at the Centre for East European Studies. He conducts research on papal diplomacy in Central and Eastern Europe in the sixteenth and seventeenth centuries, the history of the Ruthenian nobility in the Polish-Lithuanian Commonwealth between 1569 and 1648, and on Polish political thought in the second half of the fifteenth and early sixteenth centuries. He also edits historical sources; contact: h.litwin@uw.edu.pl. 